\title{
Do specialty registrars change their attitudes, intentions and behaviour towards reporting incidents following a patient safety course?
}

José D Jansma*1,2, Dorien LM Zwart ${ }^{+3,4}$, lan P Leistikow ${ }^{+3}$, Cor J Kalkman+33, Cordula Wagner ${ }^{+2,5}$ and Arnold B Bijnen+1,6

\begin{abstract}
Background: Reporting incidents can contribute to safer health care, as an awareness of the weaknesses of a system could be considered as a starting point for improvements. It is believed that patient safety education for specialty registrars could improve their attitudes, intentions and behaviour towards incident reporting. The objective of this study was to examine the effect of a two-day patient safety course on the attitudes, intentions and behaviour concerning the voluntary reporting of incidents by specialty registrars.
\end{abstract}

Methods: A patient safety course was designed to increase specialty registrars' knowledge, attitudes and skills in order to recognize and cope with unintended events and unsafe situations at an early stage. Data were collected through an 11-item questionnaire before, immediately after and six months after the course was given.

Results: The response rate at all three points in time assessed was 100\% $(n=33)$. There were significant changes in incident reporting attitudes and intentions immediately after the course, as well as during follow-up. However, no significant changes were found in incident reporting behaviour.

Conclusions: It is shown that patient safety education can have long-term positive effects on attitudes towards reporting incidents and the intentions of registrars. However, further efforts need to be undertaken to induce a real change in behaviour.

\section{Background}

Patients are at risk of suffering harm as a consequence of adverse events during their treatment [1-5]. Research has shown that a large proportion of these adverse events was considered preventable and was related to human behaviour $[2,3,5-7]$.

Voluntary and non-punitive reporting of unintended or unexpected events, which might or did lead to harm for one or more patients, can be a valuable method both to gain insight into the occurrence and causes of incidents and to identify risk factors which should be acted upon to improve safety [8-10]. Systems for reporting incidents in other high-risk sectors, such as the aviation and the petrochemical industry, have demonstrated the usefulness of this method as they resulted in measurably safer pro-

\footnotetext{
* Correspondence: j.d.jansma@mca.nl

1 Foreest Medical School, Medical Center Alkmaar, Wilhelminalaan 12, 1815JD

Alkmaar, the Netherlands

+ Contributed equally

Full list of author information is available at the end of the article
}

cesses [8]. There are three principal conditions for creating an effective reporting system: 1 ) health care workers must be aware of the importance of reporting incidents; 2) they need to know how to report an incident; and 3) they must be able to recognize risky situations [11]. Patient safety education is perceived as a major incentive to achieving an active reporting culture and thereby contributing to a reduction of risks in patient care. When the extent of adverse events in health care became visible, the need for patient safety education was adopted in policies in many countries [12-15].

For several reasons it is expected that patient safety education for registrars can lead to particularly valuable results. Firstly, registrars provide much of the direct patient care [16]. Secondly, they are considered a fragile link in the care process. Research has revealed that a lack of work experience and high pressure of work among registrars increases risky situations $[17,18]$. Besides, research showed that medical trainees' knowledge of patient safety 
across a broad range of training levels, degrees and specialties was limited [19] and that doctors have a relatively low rate of incident reporting [20]. A final argument for training registrars in patient safety is that they are considered to be a group which can achieve long-lasting benefits, as these physicians are at the beginning of their career and they are the medical specialists of the future.

Although medical education has been paying greater attention to patient safety, only a few studies have been conducted to evaluate the effectiveness of patient safety courses. Most of these studies focussed on medical students and/or did not measure long-term effects [21-25]. Only one of these studies used incident reporting attitudes and behaviour as the outcome measure. However, in that study long-term educational effects were not evaluated [21].

The objective of the current study is to examine the long-term impact of a two-day patient safety course for registrars from different specialties on their attitudes, intentions and behaviour towards the voluntary reporting of incidents. According to the Theory of Planned Behaviour, which is strongly supported by empirical evidence, attitudes and intentions, together with subjective norms, are the components that can predict behaviour [26].

\section{Methods}

\section{Course}

A patient safety course was designed according to the process-oriented teaching model of Vermunt and Verloop (1999) [27]. The goal was to increase specialty registrars' knowledge, attitudes and skills in order to recognize and cope with unintended events and unsafe situations at an early stage. The curriculum was delivered by external speakers, as well as by employees of the Patient Safety Center and the general practitioners vocational training of the University Medical Center Utrecht, the Netherlands. The course, which was part of a series of multidisciplinary courses for the registrars, consisted of two consecutive days. A mix of educational methods [28] was utilized to create an optimal learning environment with an interactive character. An overview of the course content is presented in table 1 .

\section{Data collection}

Data were collected before the course, immediately after the course and six months later. The first two assessments took place at the site of the course, where data were collected by means of an electronic voting system. For these surveys, questions were displayed on a projection screen and participants were asked to answer these questions anonymously by using a voting device. As soon as a question was answered by everyone, the group result was portrayed in a graph on the screen. Approximately six months after the course, follow-up data collection was initiated by e-mail contact with the participants. The Scientific Committee of the VU University Medical Center, the Netherlands provided a waiver for this study. National rules and regulations for health services research were followed.

\section{Questionnaire}

The same set of eleven questions was used for all three assessments (see table 2 and 3).

The first six so-called vignette questions were developed by two of the authors (CW\&ABB) and were based on their experiences in health care and patient safety research. These vignettes were intended to gain insight in the registrars' attitudes towards incident reporting in specific situations. Incident reporting in this setting meant voluntary reporting of incidents by filling out a digital registration form and sending it to a specific hospital committee. Subsequently, these reports are analysed by the committee and, if necessary, the committee gives advice for improvements that should prevent recurrence of the incident. The patient safety course stressed the importance of making a report of all unintended or unexpected events which might or did lead to harm for one or more patients. Therefore it would have been correct to consider all the cases in the questionnaire worthy of a report.

Questions 7-11 focused on attitudes, intentions and behaviour towards reporting incidents and were based on the questionnaire of Coyle et al. (2005), who measured the impact of a patient safety educational programme exclusively for family practice residents [21].

In the present study three adjustments were made to Coyle's questionnaire. Firstly, three response options were given (Yes/Cannot decide/No) instead of the two options given by Coyle (Yes/No). Secondly, the measurement of attitudes regarding the importance of incident reporting was divided into two different outcomes (with and without harm for the patient). Lastly, while Coyle asked his respondents when they had started reporting incidents, this question was omitted for this study. This was because, unlike Coyle's respondents, a major part of the current registrars had already started reporting incidents before they attended the course.

The health psychology Stages of Change Model [29], which explains intentional behavioural changes, was used as a theoretical framework for a major part of Coyle's questionnaire. This model distinguishes four consecutive stages related to behavioural change: pre-contemplation, contemplation, preparation and action [29]. Coyle gave definitions for these categories that were also incorporated into this study. Participants in the pre-contemplation stage are not currently reporting incidents and are not considering doing so in the next six months. 'Contemplators' on the other hand, are also not currently 
Table 1: Content of the patient safety course

\begin{tabular}{|c|c|c|c|}
\hline Themes & Objectives & Educational methods & References \\
\hline 1. Kick-off & $\begin{array}{l}\text { Get to know each other and } \\
\text { explore the existing } \\
\text { prejudices concerning errors } \\
\text { and incidents within the } \\
\text { group. Make agreements on } \\
\text { confidentiality. }\end{array}$ & $\begin{array}{l}\text { Plenary session; group } \\
\text { discussions; case } \\
\text { presentations. }\end{array}$ & \\
\hline $\begin{array}{l}\text { 2. Background of patient } \\
\text { safety }\end{array}$ & $\begin{array}{l}\text { Outline the history, how the } \\
\text { concepts have been } \\
\text { determined and the current } \\
\text { national and international } \\
\text { positions of patient safety. }\end{array}$ & $\begin{array}{l}\text { Plenary session; group } \\
\text { discussions. }\end{array}$ & $\begin{array}{l}\text { Baker et al. } 2004 \text { [32] } \\
\text { Willems } 2004 \text { [10] }\end{array}$ \\
\hline 3. Human Error & $\begin{array}{l}\text { Give insight into human } \\
\text { factors as a major source for } \\
\text { learning from errors and } \\
\text { incidents with a link to safety } \\
\text { in the aviation industry. }\end{array}$ & $\begin{array}{l}\text { Plenary session; group } \\
\text { discussions. }\end{array}$ & $\begin{array}{l}\text { Dekker } 2002[37] \\
\text { Casey } 2008 \text { [38] }\end{array}$ \\
\hline 4. Proceeding after an incident & $\begin{array}{l}\text { Practice skills on how to } \\
\text { approach colleagues after an } \\
\text { incident has occurred. }\end{array}$ & $\begin{array}{l}\text { Experiential learning in small } \\
\text { groups; interview, role-play, } \\
\text { reflection }\end{array}$ & $\begin{array}{l}\text { Gallagher et al. 2003 [39] } \\
\text { Chan et al. } 2005 \text { [40] } \\
\text { Gawande } 2002[41] \\
\text { Newman } 1996[42]\end{array}$ \\
\hline $\begin{array}{l}\text { 5. Medico-legal aspects of } \\
\text { critical incidents }\end{array}$ & $\begin{array}{l}\text { Transfer knowledge about the } \\
\text { medico-legal aspects of } \\
\text { critical incidents in health } \\
\text { care. }\end{array}$ & $\begin{array}{l}\text { Plenary session; group } \\
\text { discussions; summative } \\
\text { knowledge test. }\end{array}$ & Legemaate et al. 2007 [43] \\
\hline 6. Learning from errors & $\begin{array}{l}\text { Explain and apply methods for } \\
\text { analysing incidents and } \\
\text { processes such as analysing } \\
\text { the root causes and initiating } \\
\text { risk analysis. }\end{array}$ & $\begin{array}{l}\text { Plenary session; group } \\
\text { discussions; experiential } \\
\text { learning in small groups. }\end{array}$ & $\begin{array}{l}\text { Habraken et al. } 2009 \text { [44] } \\
\text { van Vuren } 1999 \text { [45] }\end{array}$ \\
\hline 7. A view from the sharp end & $\begin{array}{l}\text { Give an explanation of the } \\
\text { potential risks that can be } \\
\text { found in the design of systems } \\
\text { and products. }\end{array}$ & $\begin{array}{l}\text { Plenary session; group } \\
\text { discussions. }\end{array}$ & Barach and Small 2000 [8] \\
\hline $\begin{array}{l}\text { 8. Contact with a patient after } \\
\text { an incident }\end{array}$ & $\begin{array}{l}\text { Practice difficult } \\
\text { conversations focused on how } \\
\text { to approach a patient after an } \\
\text { incident has occurred. }\end{array}$ & $\begin{array}{l}\text { Guided role-play in small } \\
\text { groups with experienced } \\
\text { actors. }\end{array}$ & $\begin{array}{l}\text { Duclos et al. } 2005 \text { [46] } \\
\text { Gallagher et al. } 2005 \text { [47] }\end{array}$ \\
\hline $\begin{array}{l}\text { 9. Tips and Tools for daily } \\
\text { practice }\end{array}$ & $\begin{array}{l}\text { Convert the knowledge and } \\
\text { experiences gathered into } \\
\text { initiatives for improving safety } \\
\text { in daily practice. }\end{array}$ & $\begin{array}{l}\text { Plenary session; group } \\
\text { discussions. }\end{array}$ & $\begin{array}{l}\text { Jagsi et al. } 2005[17] \\
\text { Volpp et al. } 2003[16]\end{array}$ \\
\hline
\end{tabular}


Table 2: Results of vignette questions $(n=33)$

\begin{tabular}{|c|c|c|c|c|c|c|c|c|c|c|}
\hline \multirow[b]{2}{*}{$\begin{array}{l}\text { Do you consider the } \\
\text { following events worth a } \\
\text { report? }\end{array}$} & \multicolumn{3}{|c|}{ Pre-course } & \multicolumn{3}{|c|}{ Post-course } & \multicolumn{3}{|c|}{ Follow-up } & \multirow[b]{2}{*}{ Significance } \\
\hline & No & $\begin{array}{l}\text { Cannot } \\
\text { Decide }\end{array}$ & Yes & No & $\begin{array}{l}\text { Cannot } \\
\text { Decide }\end{array}$ & Yes & No & $\begin{array}{l}\text { Cannot } \\
\text { Decide }\end{array}$ & Yes & \\
\hline $\begin{array}{l}\text { 1. You bring the wrong } \\
\text { patient to the operating } \\
\text { room, you notice your } \\
\text { mistake in time and pick } \\
\text { up the right person. }\end{array}$ & $\begin{array}{c}16 \\
(48 \%)\end{array}$ & $\begin{array}{c}11 \\
(33 \%)\end{array}$ & $\begin{array}{c}6 \\
(18 \%)\end{array}$ & $\begin{array}{c}12 \\
(36 \%)\end{array}$ & $\begin{array}{c}5 \\
(15 \%)\end{array}$ & $\begin{array}{c}16 \\
(48 \%)\end{array}$ & $\begin{array}{c}9 \\
(27 \%)\end{array}$ & $\begin{array}{c}12 \\
(36 \%)\end{array}$ & $\begin{array}{c}12 \\
(36 \%)\end{array}$ & $p=0.049$ \\
\hline $\begin{array}{l}\text { 2. At the start of your } \\
\text { shift you notice that Mr. } \\
\text { B's heparin pump is } \\
\text { adjusted too high. }\end{array}$ & $\begin{array}{c}12 \\
(36 \%)\end{array}$ & $\begin{array}{c}12 \\
(36 \%)\end{array}$ & $\begin{array}{c}9 \\
(27 \%)\end{array}$ & $\begin{array}{c}4 \\
(12 \%)\end{array}$ & $\begin{array}{c}6 \\
(18 \%)\end{array}$ & $\begin{array}{c}23 \\
(70 \%)\end{array}$ & $\begin{array}{c}4 \\
(12 \%)\end{array}$ & $\begin{array}{c}3 \\
(9 \%)\end{array}$ & $\begin{array}{c}26 \\
(79 \%)\end{array}$ & $p<0.001$ \\
\hline $\begin{array}{l}\text { 3. You requested, } \\
\text { urgently, the results of a } \\
\text { laboratory test but you } \\
\text { received them much too } \\
\text { late. }\end{array}$ & $\begin{array}{c}19 \\
(58 \%)\end{array}$ & $\begin{array}{c}6 \\
(18 \%)\end{array}$ & $\begin{array}{c}8 \\
(24 \%)\end{array}$ & $\begin{array}{c}10 \\
(30 \%)\end{array}$ & $\begin{array}{c}5 \\
15 \%)\end{array}$ & $\begin{array}{c}18 \\
(55 \%)\end{array}$ & $\begin{array}{c}3 \\
(9 \%)\end{array}$ & $\begin{array}{c}13 \\
(39 \%)\end{array}$ & $\begin{array}{c}17 \\
(52 \%)\end{array}$ & $p<0.001$ \\
\hline $\begin{array}{l}\text { 4. The treatment policy } \\
\text { of Mrs. X changed, but so } \\
\text { far there is no } \\
\text { notification of this in her } \\
\text { status. }\end{array}$ & $\begin{array}{c}28 \\
(85 \%)\end{array}$ & $\begin{array}{c}2 \\
(6 \%)\end{array}$ & $\begin{array}{c}3 \\
(9 \%)\end{array}$ & $\begin{array}{c}12 \\
(36 \%)\end{array}$ & $\begin{array}{c}10 \\
(30 \%)\end{array}$ & $\begin{array}{c}11 \\
(33 \%)\end{array}$ & $\begin{array}{c}9 \\
(27 \%)\end{array}$ & $\begin{array}{c}11 \\
(33 \%)\end{array}$ & $\begin{array}{c}13 \\
(39 \%)\end{array}$ & $p<0.001$ \\
\hline $\begin{array}{l}\text { 5. You notice that the } \\
\text { ampoules are not placed } \\
\text { as usual, you were not } \\
\text { informed about a } \\
\text { change in policy. }\end{array}$ & $\begin{array}{c}30 \\
(91 \%)\end{array}$ & $\begin{array}{c}1 \\
(3 \%)\end{array}$ & $\begin{array}{c}2 \\
(6 \%)\end{array}$ & $\begin{array}{c}17 \\
(52 \%)\end{array}$ & $\begin{array}{c}7 \\
(21 \%)\end{array}$ & $\begin{array}{c}9 \\
(27 \%)\end{array}$ & $\begin{array}{c}8 \\
(24 \%)\end{array}$ & $\begin{array}{c}17 \\
(52 \%)\end{array}$ & $\begin{array}{c}8 \\
(24 \%)\end{array}$ & $p<0.001$ \\
\hline $\begin{array}{l}\text { 6. On hindsight it } \\
\text { became clear that the } \\
\text { diagnosis of Mr. M was } \\
\text { wrong, the patient did } \\
\text { not experience any } \\
\text { disadvantages. }\end{array}$ & $\begin{array}{c}23 \\
(70 \%)\end{array}$ & $\begin{array}{c}8 \\
(24 \%)\end{array}$ & $\begin{array}{c}2 \\
(6 \%)\end{array}$ & $\begin{array}{c}14 \\
(42 \%)\end{array}$ & $\begin{array}{c}9 \\
(27 \%)\end{array}$ & $\begin{array}{c}10 \\
(30 \%)\end{array}$ & $\begin{array}{c}18 \\
(55 \%)\end{array}$ & $\begin{array}{c}5 \\
(15 \%)\end{array}$ & $\begin{array}{c}10 \\
(30 \%)\end{array}$ & NS \\
\hline
\end{tabular}


Table 3: Incident reporting attitudes, intentions and behaviour $(n=33)$

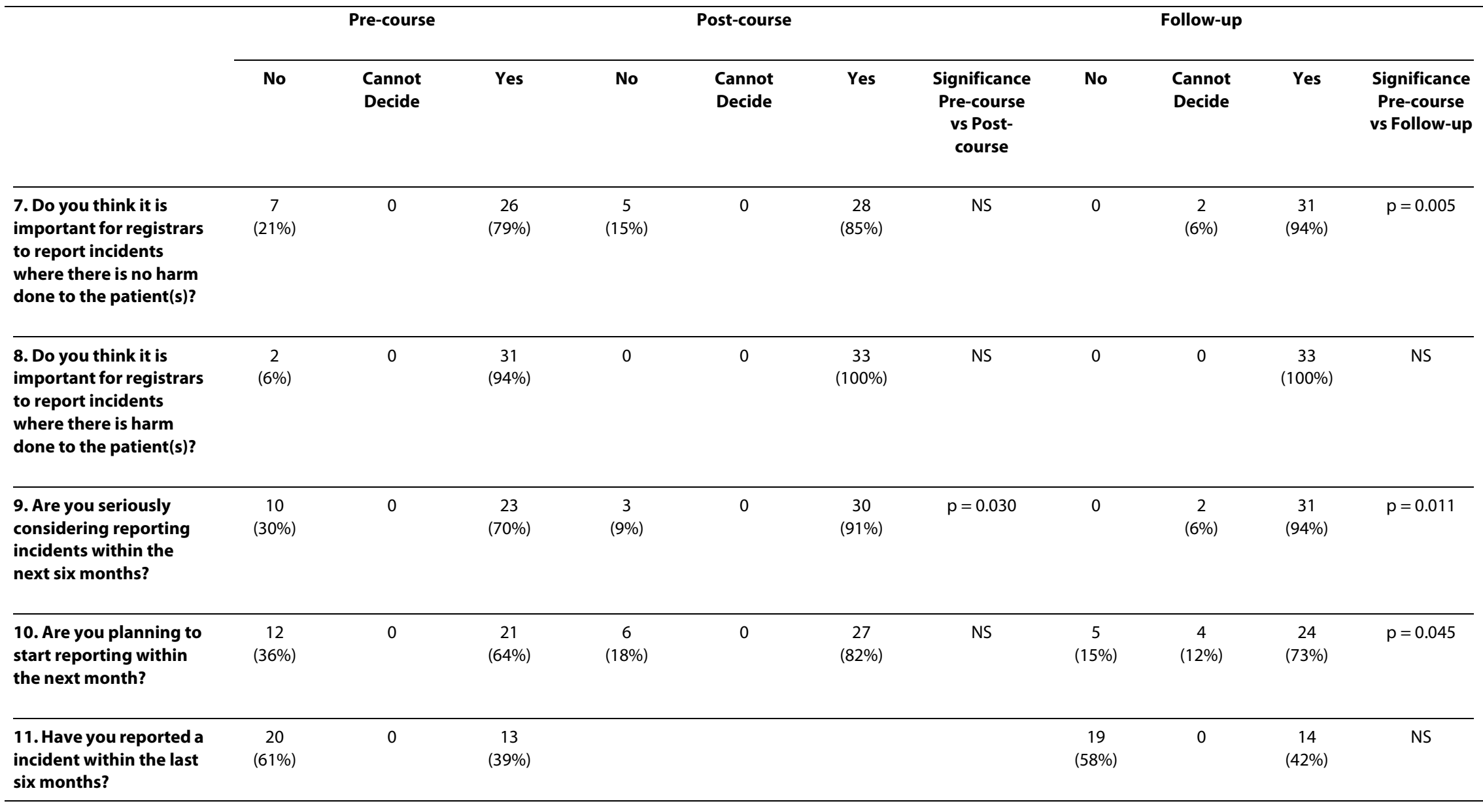


reporting incidents, but are planning to do so within the next six months. Individuals in the preparation stage are not currently reporting incidents but in these cases are planning to start reporting within the next 30 days. In the action stage participants have begun reporting incidents within the last six months [21].

\section{Analysis}

Data were analysed using SPSS version 15.0. For each question the percentages of the three different categories of answer (Yes/Cannot decide/No) were calculated. The significance of the differences between the three points in time was determined with Pearson Chi-Square tests $(\mathrm{p}<$ 0.05). To enable the use of the Fisher's exact test, for analysing questions 7-12, two answer categories were created: 1) Yes/Cannot decide and 2) No. To analyse the six vignette questions, a sum variable was created.

After the patient safety course we measured significant positive changes in attitudes, these changes remained stable over time, so no significant changes were found between the post-course and follow-up measurement. Therefore there was no linear trend in time. Regression analysis showed there was no correlation between the measurement and the questionnaires' outcomes ( $\mathrm{R} \mathrm{Sq}$ was only 0.1 ).

\section{Table 4: Characteristics of the study participants}

\begin{tabular}{ll} 
Age, years & $30-35$ \\
Range & 32 \\
Median age & \\
Sex, $\mathrm{n}(\%)$ & $12(36)$ \\
Male & $21(64)$ \\
Female & \\
Year of residency during & \\
course, $\mathrm{n}$ (\%) & \\
First & $4(12)$ \\
Between first and last & $18(55)$ \\
Last & $10(30)$ \\
Missing & $1(3)$ \\
& \\
Discipline, $\mathrm{n}$ (\%) & \\
General practice & $10(30)$ \\
Anaesthesiology & $10(30)$ \\
Dermatology & $4(12)$ \\
Internal medicine & $4(12)$ \\
Other & $5(15)$ \\
\hline
\end{tabular}

\section{Results}

Participants

In December 2006, 33 registrars from the district of Utrecht attended the patient safety course. Table 4 shows the characteristics of the study participants. For all three assessments the response rate was $100 \%(n=33)$. The median response time at follow-up was 16 days after follow-up data collection started.

\section{Baseline}

At the first measurement a minority of the registrars considered the vignettes worth reporting (figure 1). A majority of respondents judged reporting by registrars important for incidents with harm, as well as incidents without harm for the patient(s). A majority of the participants recorded an intention to report incidents, though less than half of the registrars indicated that they have reported an incident within the last six months. An overview of the exact answers given at the separate measurements is given in table 2 and 3 .

\section{Changes in reporting attitudes (question 1 - 8)}

After the course all vignettes more often were considered worth reporting, in five out of six the changes were significant (table 2). Analysis of the constructed sum variable of the six vignette questions shows that immediately after the course, as well as during follow-up, there were significant changes in attitudes towards reporting incidents $(\mathrm{p}<$ 0.001 ). After attending the patient safety course, registrars more often considered it worth reporting the incidents proposed in the questionnaire (figure 1).

Measurements of the registrars' views concerning the necessity of reporting incidents without harm (question 7) or with harm (question 8) to the patient both demonstrate that after the course more registrars judged report-

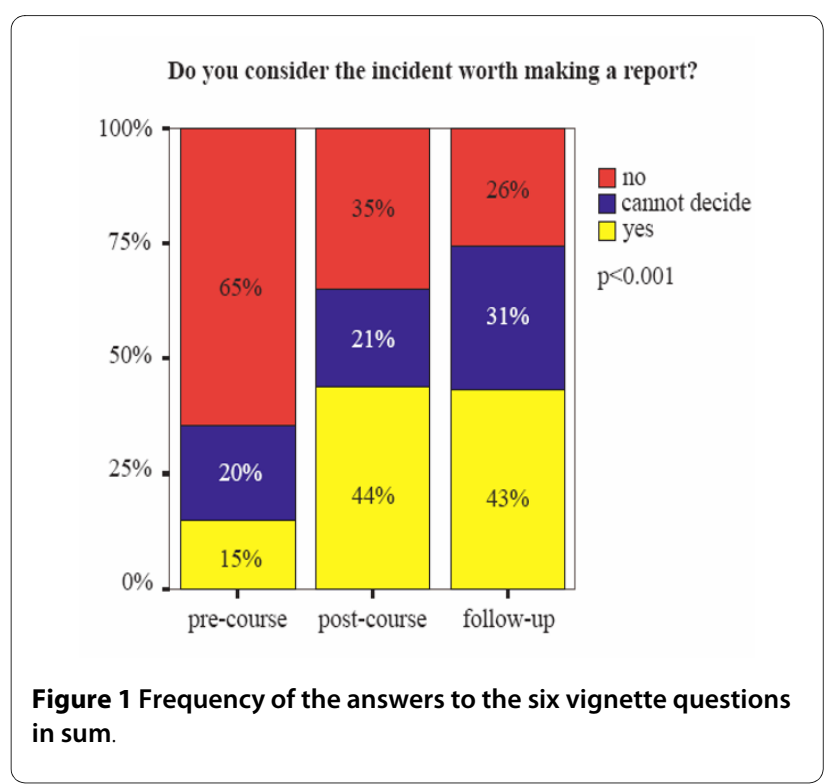


ing by registrars to be important. These changes were not only significant for question 7 when the pre-course measurement was compared to the follow-up measurement.

\section{Changes in reporting intentions (question 9\&10)}

Intentions to report incidents within the next six months (table 3, question 9) showed an increase immediately after the course as well as during follow-up. Plans to report incidents within the next month also increased, but this change only reached statistically significant levels when pre-course and follow-up measurements were compared (table 3, question 10).

\section{Changes in reporting behaviour (question 11)}

At the follow-up the number of registrars who declared they had reported an incident in the last six months had increased by one, this change was not significant.

\section{Discussion}

Incident reporting by health care workers is considered an important step towards improving patient safety. This study focussed on a course that aimed at increasing the knowledge, attitudes and skills of registrars, in order to improve the safety of patients. The objective of this study was to assess the impact of the course on attitudes, intentions and behaviour of the participants towards reporting incidents.

The study led to three major results. Firstly, after attending the course the registrars' ability to assess what kind of incident deserves reporting had improved. Secondly, after the course, intentions to report incidents increased significantly (contemplation and preparation stage). Thirdly, no significant changes were found in incident reporting behaviour (action stage).

The first two results indicate that the course had a positive impact on registrar attitudes. The elements of the course that may particularly have contributed to this positive impact were the group discussions about incident reporting and experiences with incidents that were outlined by teachers and registrars. However, as the third result shows, a discrepancy remains between registrars' intentions to report incidents and their behaviour. This discrepancy was also found in other studies $[21,30]$.

\section{Reporting barriers}

It is unlikely that the participants did not report incidents because of the absence of these in their work, as research revealed that registrars are regularly involved in incidents [1-5,31-33]. This study did not make an inventory of the possible barriers that might discourage incident reporting among the registrars. However, other publications $[20,21,34]$ suggest that there are several barriers, related to human as well as system factors, that could hinder incident reporting. These included: time constraints, complex reporting systems, no perceived benefits, forget- fulness, no encouragement from the faculty, no timely and high quality feedback on medical event reports, risks to one's career and personal reputation and a lack of knowledge of what to report.

Apart from the individual barriers, the participants in this study constitute just a small proportion of the entire population of the health care workers in their district. The impact of education on behavioural change may suffer if only a small part of the team members are trained instead of the entire health care team [35]. To achieve permanent changes in engrained behavioural patterns it is important to focus not only on individual attitudes and intentions, but also on a stimulating environment, including hospital culture and patient safety policies [26].

It is expected that explanations for the absence of reports may vary between different settings, as every organisation has its own particular policy and culture. For example, at the time of this study, incident reporting in Dutch general practices was rare, and incident reporting systems were mostly not available [36]. Research should be conducted in order to reveal the barriers that these registrars experienced and that discouraged them from reporting incidents.

\section{Study limitations}

This study focussed on one group of just 33 registrars. This number of participants might have been too small to detect changes in behaviour. Furthermore, the results could be very much dependent of the specific setting in this study hospital. Another limiting factor is that the outcomes were based on the perception of the respondents, which might provoke social desirability bias. The fact that the first two measurements were carried out anonymously and that the data were collected by an independent researcher hopefully has minimized this bias. Also, a 'testing effect' may have influenced the internal validity of this study. If respondents are repeatedly asked to fill out a questionnaire, their score might improve each subsequent time because of practice, familiarity or awareness. However, we believe that the effect of possible testing bias was minimal in this study because the second and third measurements were about six months apart. Lastly, the questionnaire that was used was not validated. Although a major part of the questionnaire had been used before elsewhere [21], its validity towards attitudes and intentions still remains to be proven.

\section{Directions for future research}

Thus, a change in attitudes and intentions is not sufficient to induce a real change in behaviour. Therefore, barriers, perceived by registrars to discourage the reporting of incidents, should be analyzed. This can be considered a starting point in overcoming these barriers. A further step should be taken to ensure the benefits of patient 
safety education to continue throughout the educational career. Investigating the role of the participants' characteristics is recommended for future evaluations of patient safety education. Previous research showed that the degree of knowledge about patient safety varied significantly depending on characteristics such as the year of training, specialty, gender and age [19].

\section{Conclusions}

This study showed that multispecialty patient safety education can have positive effects, both immediately and in the long-term, on attitudes towards reporting incidents and the intentions of specialty registrars. Therefore, patient safety education should be integrated within medical education. Although registrars in this study judged that reporting incidents by registrars is important, there is a gap between the registrars' intentions to report incidents and their actual behaviour. Therefore, further steps are needed to stimulate a real change in behaviour.

\section{Authors' information}

José D. Jansma, MSc, is a PhD student of the research programme Patient Safety in the Netherlands. She is working for the Foreest Medical School of the Medical Center Alkmaar, the Netherlands, and the Department of Public and Occupational Health, EMGO Institute, VU University Medical Center, the Netherlands.

Dorien L.M. Zwart, MD, is general practitioner and assistant professor of the general practitioner vocational training of the Julius Center for Health Sciences and Primary Care, University Medical Center Utrecht. In addition, she is researcher at the University Medical Center Utrecht Patient Safety Center, the Netherlands.

Ian P. Leistikow, MD, is coordinator of the University Medical Center Utrecht Patient Safety Center, the Netherlands.

Cor J. Kalkman, MD, $\mathrm{PhD}$, is professor in anaesthesiology and head of the University Medical Center Utrecht Patient Safety Center, the Netherlands.

Cordula Wagner, MA, PhD, is head of research area 'Quality and Organisation of hospital- and long-term care' at NIVEL Netherlands Institute for Health Services Research. In addition, she is supervisor of the Dutch research programme on patient safety in hospitals at the department of public and occupational health/EMGO Institute, VU Medical Center, the Netherlands.

Arnold B. Bijnen, MD, PhD, is a general gastro-intestinal surgeon at the Medical Center Alkmaar. He has been appointed professor of surgery at the VU University Medical Center for teaching and postgraduate training.

\section{Competing interests}

The authors declare that they have no competing interests.

\section{Authors' contributions}

JDJ collected and analyzed the data, and wrote the manuscript. DLMZ, IPL and CJK drew up the educational approach, and co-wrote the manuscript. CW designed the study, collected the data, and co-wrote the manuscript. ABB designed the study, collected the data and co-wrote the manuscript. All authors read and approved the final manuscript.

\section{Acknowledgements}

We would like to thank all the specialty registrars for their cooperation. With financial support from the Foreest Medical School of the Medical Center Alkmaar, and the Ministry of Health, Welfare and Sport in the Netherlands this study was conducted as part of the Dutch Patient Safety Research Programme.

\section{Author Details}

'Foreest Medical School, Medical Center Alkmaar, Wilhelminalaan 12, 1815JD Alkmaar, the Netherlands, ${ }^{2}$ EMGO Institute for Health and Care Research, VU University Medical Center, Van der Boechorststraat 7, 1081BT Amsterdam, the Netherlands, ${ }^{3}$ University Medical Center Utrecht Patient Safety Center, Heidelberglaan 100, 3584CX Utrecht, the Netherlands, ${ }^{4}$ University Medical Center Utrecht, Julius Center for Health Sciences and Primary Care, Heidelberglaan 100, 3584CX Utrecht, the Netherlands, 5 NIVEL Netherlands Institute for Health Services Research, Otterstraat 118 - 124, 3500BN Utrecht, the Netherlands and $6 \mathrm{VU}$ University Medical Center, Institute for Education and Training, Van der Boechorststraat 7, 1081BT Amsterdam, the Netherlands

Received: 6 July 2009 Accepted: 23 April 2010

Published: 23 April 2010

\section{References}

1. Brennan TA, Leape $L L$, Laird NM, Hebert L, Localio AR, Lawthers AG, et al:: Incidence of adverse events and negligence in hospitalized patients. Results of the Harvard Medical Practice Study I. New England Journal of Medicine 1991, 324:370-376.

2. Kohn LT, Corrigan JM, Donaldson MS: To err is human, building a safer healthcare system 2000.

3. Vincent C, Neale G, Woloshynowych M: Adverse events in British hospitals: preliminary retrospective record review. British Medical Journal 2001, 322:517-519.

4. Davis P, Lay-Yee R, Briant R, Ali W, Scott A, Schug S: Adverse events in New Zealand public hospitals I: occurrence and impact. New Zealand Medical Journal 2002, 115:U271.

5. Zegers M, de Bruijne MC, Wagner C, Hoonhout LHF, Waaijman R, Smits M, et al:: Adverse events and potentially preventable deaths in Dutch hospitals. Results of a retrospective patient record review study. Quality and Safety in Health Care 2009.

6. Leape LL, Brennan TA, Laird N, Lawthers AG, Localio AR, Barnes BA, et al: The nature of adverse events in hospitalized patients. Results of the Harvard Medical Practice Study II. New England Journal of Medicine 1991, 324:377-384.

7. Davis P, Lay-Yee R, Briant R, Ali W, Scott A, Schug S: Adverse events in New Zealand public hospitals II: preventability and clinical context. NeW Zealand Medical Journal 2003, 116:U624.

8. Barach P, Small SD: Reporting and preventing medical mishaps: lessons from non-medical near miss reporting systems. British Medical Journal 2000, 320:759-763.

9. Reason J: Understanding adverse events: human factors. Quality and Safety in Health Care 1995, 4:80-89.

10. Willems R: Hier werk je veilig of je werkt hier niet. Sneller beter - de veiligheid in de zorg. [Here you work safely, or you don't work here. Better faster - safety in health care]. Shell Netherlands 2004. Ref Type: Report

11. Walton MM, Elliott SL: Improving safety and quality: how can education help? Medical Journal of Australia 2006, 184:S60-S64.

12. COGME, NACNEP: Collaborative education to ensure patient safety. Council on Graduate Medical Education and the National Advisory Council on Nurse Education and Practice 2000.

13. Doing what counts for patient safety: federal actions to reduce medical errors and their impact: report of the Quality Interagency Coordination Task Force (QuIC) to the President Rockville, MD: US Department of Health and Human Services; 2000. 
14. National Patient Safety Education Framework. The Australian Council for Safety and Quality in Health Care; 2005. Ref Type: Report

15. NVZ, OMS, LEV\&V, VVN, NFUMC: Veiligheidsprogramma voorkom schade, werk veilig in de Nederlandse ziekenhuizen. [Safety program prevent harm, work safely in Dutch hospitals]. NVZ vereniging van ziekenhuizen, Orde van Medisch Specialisten, Landelijk Expertisecentrum Verpleging \& Verzorging, Verpleegkundigen \& Verzorgenden Nederland en Nederlandse Federatie van Universitair Medische Centra 2007. Ref Type: Report

16. Volpp KG, Grande D: Residents' suggestions for reducing errors in teaching hospitals. N Engl J Med 2003, 348:851-855.

17. Jagsi R, Kitch BT, Weinstein DF, Campbell EG, Hutter M, Weissman JS: Residents report on adverse events and their causes. Arch Intern Med 2005, 165:2607-2613.

18. Battles JB, Shea CE: A system of analyzing medical errors to improve GME curricula and programs. Acad Med 2001, 76:125-133.

19. Kerfoot BP, Conlin PR, Travison T, McMahon GT: Patient safety knowledge and its determinants in medical trainees. Journal of General Internal Medicine 2007, 22:1150-1154.

20. Evans SM, Berry JG, Smith BJ, Esterman A, Selim P, O'Shaughnessy J, et al: Attitudes and barriers to incident reporting: a collaborative hospital study. Quality and Safety in Health Care 2006, 15:39-43.

21. Coyle YM, Mercer SQ, Murphy-Cullen CL, Schneider GW, Hynan LS: Effectiveness of a graduate medical education program for improving medical event reporting attitude and behavior. Quality and Safety in Health Care 2005, 14:383-388.

22. Halbach JL, Sullivan LL: Teaching medical students about medical errors and patient safety: evaluation of a required curriculum. Academic Medicine 2005, 80:600-606.

23. Madigosky WS, Headrick LA, Nelson K, Cox KR, Anderson T: Changing and sustaining medical students' knowledge, skills, and attitudes about patient safety and medical fallibility. Acad Med 2006, 81:94-101.

24. Moskowitz E, Veloski JJ, Fields SK, Nash DB: Development and evaluation of a 1-day interclerkship program for medical students on medical errors and patient safety. Am J Med Qual 2007, 22:13-17.

25. Weingart SN, Tess A, Driver J, Aronson MD, Sands K: Creating a quality improvement elective for medical house officers. J Gen Intern Med 2004, 19:861-867.

26. Ajzen I, Fishbein M: The influence of attitudes on behavior. In The handbook of attitudes Edited by: Albarracín D, Johnson BT, Zanna MP. Mahwah, NJ: Erlbaum; 2005:173-221.

27. Vermunt JD, Verloop $\mathrm{N}$ : Congruence and friction between learning and teaching. Learning and Instruction 1999, 9:257-280.

28. Chambers R, Wakley G, lqbal Z, Field S: Prescription for learning. Techniques, games and activities Radcliffe Medical Press; 2002.

29. Prochaska JO, DiClemente CC: Stages of change in the modification of problem behaviors. Prog Behav Modif 1992, 28:183-218.

30. Kaldjian LC, Jones EW, Wu BJ, Forman-Hoffman VL, Levi BH, Rosenthal GE: Reporting medical errors to improve patient safety: a survey of physicians in teaching hospitals. Arch Intern Med 2008, 168:40-46.

31. Proctor ML, Pastore J, Gerstle JT, Langer JC: Incidence of medical error and adverse outcomes on a pediatric general surgery service. Journal of Pediatric Surgery 2003, 38:1361-1365.

32. Baker GR, Norton PG, Flintoft V, Blais R, Brown A, Cox J, et al.: The Canadian Adverse Events Study: the incidence of adverse events among hospital patients in Canada. Canadian Medical Association Journal 2004, 170:1678-1686.

33. Wagner C, de Bruyne MC: Onbedoelde schade in Nederlandse ziekenhuizen. Publiekssamenvatting. [Unintended harm in Dutch hospitals. Public summary] 2007. Ref Type: Report

34. Elder NC, Graham D, Brandt E, Hickner J: Barriers and motivators for making error reports from family medicine offices: a report from the American Academy of Family Physicians National Research Network (AAFP NRN). J Am Board Fam Med 2007, 20:1 15-123.

35. Baker DP, Gustafson S, Beaubien JM, Salas E, Barach P: Medical Teamwork and Patient Safety: The Evidence-Based Relation. Washington, DC, American Institute for Research; 2003. Ref Type: Report

36. Zwart DLM, Steerneman AHM, van Rensen ELJ, Kalkman CJ, Verheij TJM: Feasibility of centre-based incident reporting in primary health care: the SPIEGEL-study. Quality and Safety in Health Care (in press) 2010 in press.
37. Dekker S: The field guide to human error investigations Ashgate Publishing Limited; 2002.

38. Casey SM: Set phasers on stun and other true tales of design, technology and human error 2nd edition. Atlantic Books; 2008.

39. Gallagher TH, Waterman AD, Ebers AG, Fraser VJ, Levinson W: Patients' and physicians' attitudes regarding the disclosure of medical errors. JAMA 2003, 289:1001-1007.

40. Chan DK, Gallagher TH, Reznick R, Levinson W: How surgeons disclose medical errors to patients: a study using standardized patients. Surgery 2005, 138:851-858.

41. Gawande AA: Complications, a surgeons notes to an imperfect science Picador USA; 2002.

42. Newman MC: The emotional impact of mistakes on family physicians. Arch Fam Med 1996, 5:71-75.

43. Legemaate J, van Everdingen JJ, Kievit J, Stappers JW: Openheid over fouten in de gezondheidszorg. [Frankness regarding errors in medical care]. Ned Tijdschr Geneeskd 2007, 151:319-322.

44. Habraken MM, Schaaf TW Van der, Leistikow IP, Reijnders-Thijssen PM: Prospective risk analysis of health care processes: a systematic evaluation of the use of HFMEA in Dutch health care. Ergonomics 2009, 52:809-819

45. van Vuren: Organisational failure: lessons from industry applied in the medical domain. Safety Science 1999, 33:13-29.

46. Duclos CW, Eichler M, Taylor L, Quintela J, Main DS, Pace W, et al.: Patient perspectives of patient-provider communication after adverse events. Int J Qual Health Care 2005, 17:479-486.

47. Gallagher TH, Levinson W: Disclosing harmful medical errors to patients: a time for professional action. Arch Intern Med 2005, 165:1819-1824.

\section{Pre-publication history}

The pre-publication history for this paper can be accessed here: http://www.biomedcentral.com/1472-6963/10/100/prepub

\section{doi: $10.1186 / 1472-6963-10-100$}

Cite this article as: Jansma et al., Do specialty registrars change their attitudes, intentions and behaviour towards reporting incidents following a patient safety course? BMC Health Services Research 2010, 10:100

\section{Submit your next manuscript to BioMed Central and take full advantage of:}

- Convenient online submission

- Thorough peer review

- No space constraints or color figure charges

- Immediate publication on acceptance

- Inclusion in PubMed, CAS, Scopus and Google Scholar

- Research which is freely available for redistribution
C) Biomed Central 